\title{
IMPORTED MUSIC SCORES IN THE POSSESSION OF THE GOZZE FAMILY IN DUBROVNIK
}

\author{
VJERA KATALINIĆ \\ Hrvatska akademija znanosti i umjetnosti, Zagreb
}

\begin{abstract}
Izvleček: Plemiška družina Gozze je imela v Dubrovniku občudovanja vredno zbirko muzikalij, večinoma iz poznega 18. in začetka 19. stoletja. Gradivo se je deloma ohranilo v glasbeni zbirki frančiškanskega samostana $v$ dubrovniku med gradivom iz časa Dubrovniške republike, ki ga tam hranijo od začetka 19. stoletja. Ohranjena je tudi knjižica, katalog muzikalij. Po opombah na samih notah je mogoče vzpostaviti zvezo med samim gradivom in beležkami v katalogu. Tako tiski kot tudi rokopisi so bili večinoma kupljeni $v$ tujini, iz njih pa danes lahko razberemo vrsto informacij o njihovem izvoru, okoliščinah izvedb itd. Vse to pa odseva glasbeni okus družine Gozze.
\end{abstract}

Ključne besede: Dubrovnik, katalog muzikalij, frančiškanski samostan, družina Gozze, glasbeni kopisti, glasbeni založniki, 18. in 19. stoletje.
Abstract: The noble Gozze family in Dubrovnik maintained a respectable collection of musical material dating mostly from the late eighteenth and early nineteenth centuries. It has been partly preserved in the music collection of the Monastery of the Friars Minors in Dubrovnik, forming part of the material dating from the time of the Republic of Ragusa (Dubrovnik) kept there since the mid-nineteenth century. There is also a booklet - actually a catalogue - listing their musical material. On the basis of its notes on this music collection, a link between the catalogue and the material can be established. The prints and manuscripts were mostly purchased from abroad, and these provide various kinds of information on their origin, the context of their performance etc., thereby illustrating the taste of their owners.

Keywords: Dubrovnik, catalogue of music sources, Friars Minor, Gozze family, music copyists, music publishers, eighteenth and nineteenth centuries.

\section{Introductory Remarks}

If one may paraphrase Plato's connection between the quality of art - in this case, music - and the quality of a state, the Republic of Dubrovnik might well be characterized as a traditional one, with good relations among its broad cultural circle, cautious, modest in its output and, certainly, not prodigious or boastful. The facts we know about its eighteenth-century history, as well as the preserved musical material, testify to its well-educated nobility, its representative Rector's Chapel with a centuries-old tradition, its Cathedral orchestra and the education in music offered at the Jesuit College as well 
as privately. This small state, with some forty to fifty thousand (or fewer) inhabitants, ${ }^{1}$ which formally acknowledged the sovereignty of the Croatian-Hungarian kings, who tried to keep Venetian appetites at a distance, and - for balance - also had to pay tribute to the Ottomans, was very cautious about letting new ideas penetrate into their "safe community." Hence its cautious government allowed the first printshop only in 1783 - and then only for textual material, so that musical scores still had to be imported. Moreover, Dubrovnik's Senate never took a decision to establish a permanent theatre group or even an opera house. It was easier to exercise control over the performances of Italian itinerant companies, which toured along the Eastern shores of the Adriatic, performing the standard repertoire in its adapted theatre (formerly an arsenal) - and it was definitely cheaper. Yet the philosopher and physicist (Abbé) Ruđer Bošković complained in 1748 that the "atmosphere of his native city will be poisoned by attractive actresses and by the competition to win their favour,"2 because local amateur theatre companies admitted only male performers.

\section{Music Collections in Dubrovnik}

An evaluation of musical taste in the Republic of Dubrovnik at the beginning of this text has been made possible by facts gleaned from secondary sources as well as from the rich music collections still preserved in the sacred and secular institutions within its city walls. Nevertheless, natural catastrophes (such as the disastrous earthquake in 1676 and the ensuing fires) and occupying armies (French and Austrian) ${ }^{3}$ radically diminished its estimable patrimony. Still, several points of musicological interest from primary sources can offer information about the musical past of the city. On this occasion, the collection of the Dominican Monastery, with sources relating to church music from the eleventh century onwards, and the rich collection of some seven hundred eighteenth- and early nineteenth-century libretti, held by the Scientific Library, as well as some smaller private and public collections, will interest us less. The focus of the present investigation is the large music collection of the Friars Minor in Dubrovnik, comprising almost eight thousand items. ${ }^{4}$ Apart from the "sacred" component, containing musical material dating from the eleventh century up to the present, it houses a fairly extensive amount of secular music originating mostly from private collections. The credit for this work of collecting goes to Ivan Evanđelist Kuzmić (1807-1880), a member of the Franciscan community and a pharmacist, historian, organist and composer, who went from door to door in the mid-nineteenth century in order to collect musical material lying, largely forgotten, in the attics of the houses and villas of local noble families. By then, the glorious past of the Republic of Dubrovnik, whose existence was brought to an abrupt end in

1 On the question of Dubrovnik's population, see Krivošić, Stanovništvo Dubrovnika.

2 Beritić, "Iz povijesti," 28.

3 The French army entered the city in 1806 and in 1808 abolished the Republic, while the Habsburg Empire gained the territory of the former Republic at the Congress of Vienna.

4 For more information on the composers connected to Dubrovnik, see Demović, Glazba $i$ glazbenici; on the Franciscan music collection, see Tuksar, "Glazbeni arhiv." 
1808 by Napoleon's army, lived on only in the nostalgic memory of its aristocratic offspring. The consequences of its absorption, in 1815, into the framework of the Habsburg Empire, with simultaneous economic and social changes, led to its decline and impoverishment. Still, the inscriptions and notes found within the collected and preserved musical material can trace a picture of the music interests of its noble inhabitants.

These notes provide information on Dubrovnik families with Italian names (Stulli, Pellegrini), Italianized ones, which would mostly adopt a Slavic form during the nineteenth century (Natali $\rightarrow$ Božidarević, Sorgo $\rightarrow$ Sorkočević, Chersa $\rightarrow$ Krša, Zuzzeri $\rightarrow$ Zuzorić, Pozza $\rightarrow$ Pucić or Pučić), and Croatian names (Androvich, Moncovich, Maroevich, Milkovich, Ivankovich, Casnacich, Ascich, Barich, Lepesc), all of them written, however, in the Italian manner. The nineteenth century also reveals some German names (Schwarz), ${ }^{5}$ thus uncovering different layers in the cultural traditions of the city.

The name that occurs on the majority of the signed musical items is that of the noble Gozze family. Its origin, stretching back at least to the twelfth century, ${ }^{6}$ and the importance of its members (diplomats, philosophers, artists and seafarers) made it one of the richest and most influential families among the old nobility of the Republic of Dubrovnik. According to the statistics for offices held by the Republic's supreme governing class, ${ }^{7}$ members of the Gozze clan occupied second place, holding 306 posts $(12.01 \%$ of the total) during the period 1751-1807, while the Sorgo family led the field in this respect, occupying five hundred posts during the same period (19.63\% of the total). ${ }^{8}$ As educated intellectuals, the Gozze family owned one of the largest libraries in the Republic, and many inscriptions in preserved archival material testify to their interest in the Arts, in addition to music.

Gozze family members collected sheet music for their own use: probably exclusively for domestic performance, either by themselves or by members of the Rector's orchestra or that of the Cathedral, but at any rate within the confines of their town houses or summer villas. The contents of the collection can be reconstructed - at least in part - thanks to the preserved catalogue (or, more precisely, list) of their music, as well as from the music itself, which bears the signatures of certain family members; together, these elements are distributed among some 240 boxes in the music collection of the Franciscan Library.

\section{The Catalogue or Elenco}

The author of the music catalogue is Paolo Baldasare di Gozze (Pavo Baldov Gozze, 1778-1838), ${ }^{9}$ a close friend of the diplomat and composer Antonio Sorgo (Antun Sorkočević),

5 Katalinić, "Glazbeni arhiv ," 623-664.

6 Their nickname "Pecorario" shows that they were sheep-farmers before their migration from Livno (Bosnia) to Dubrovnik in the twelfth century. An extended reconstruction of the family trees of the Pecorario (and Gozze) clans, with information on their origin, is presented in Vekarić, Vlastela grada Dubrovnika, 3:91-149 (Gozze: 97-142; Bassegli-Gozze: 142-143).

7 Ćosić and Vekarić, Dubrovačka vlastela.

8 The diplomats and composers Luka Sorgo and his son Antun also participated in these duties as senators, ambassadors or similar.

9 All these names are given also in Croatian, because this is the language they mostly used in their 


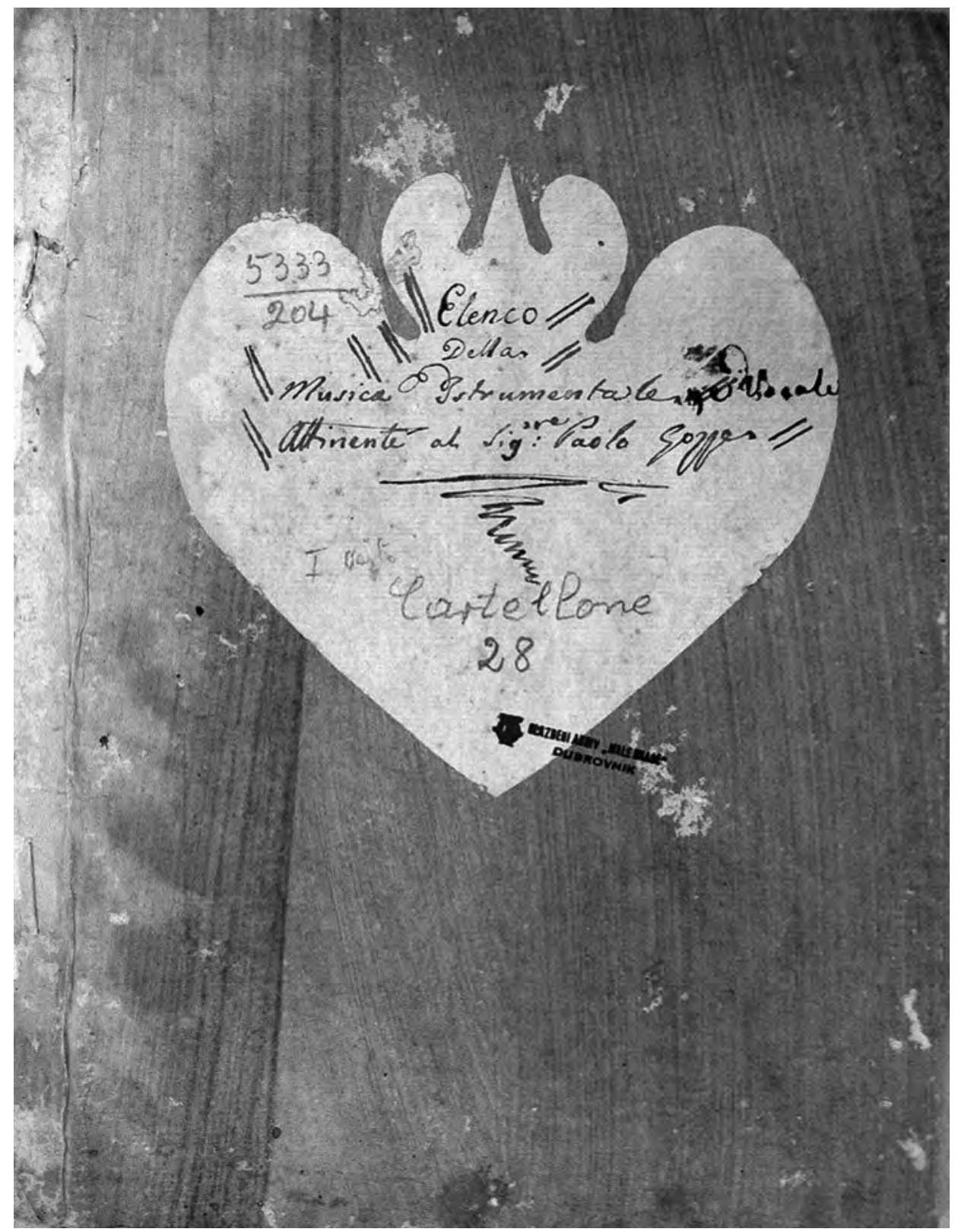

Figure 1a Title page of the catalogue of music scores by Paolo Gozze, preserved in the Dubrovnik Franciscan monastery (Dubrovnik, Samostan Male braće, Glazbena zbirka, 204/5666; reproduced with kind permission). 


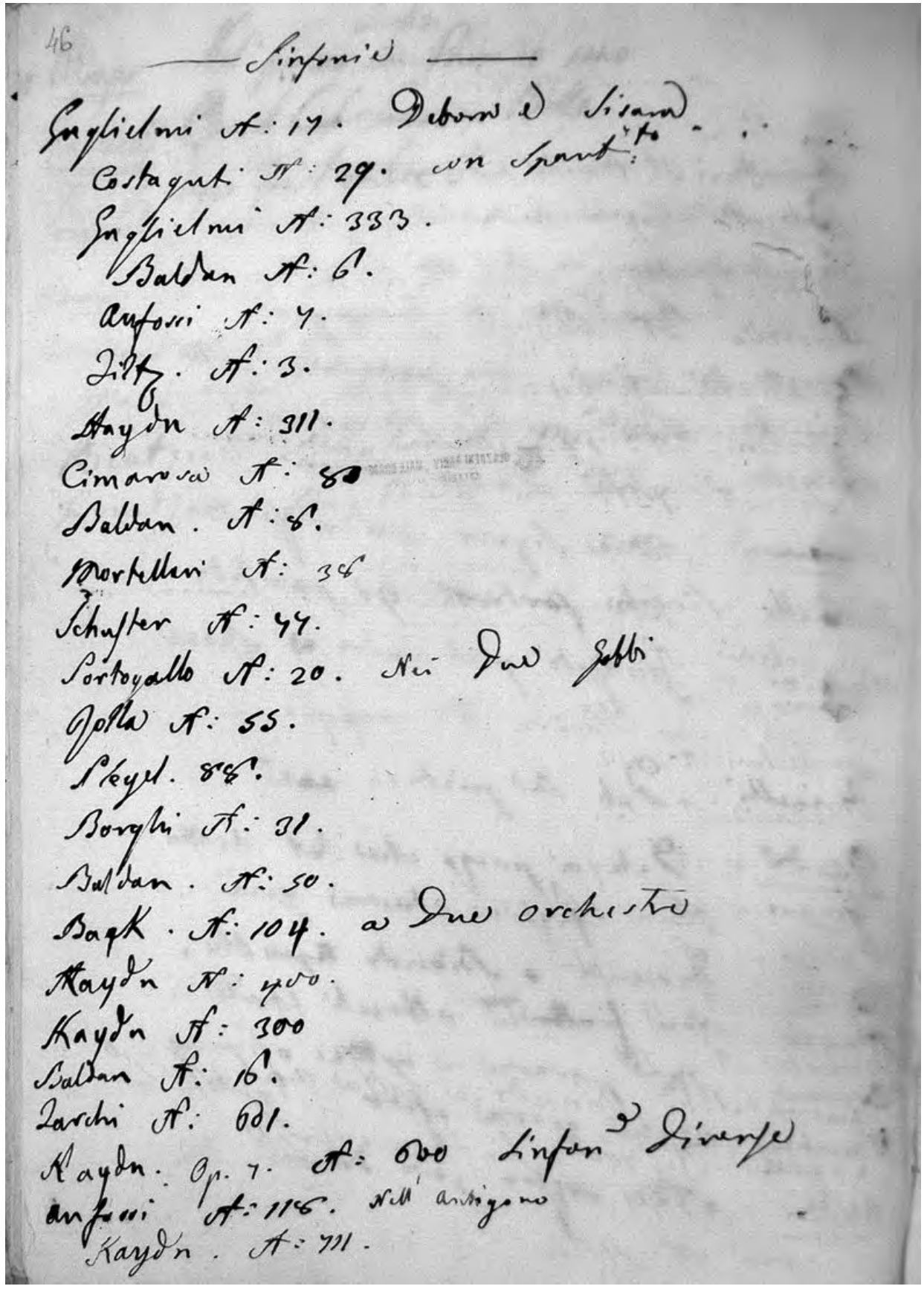

Figure 1b A page of orchestral pieces in the Gozze catalogue where, under the name of "Sinfonie", both symphonies by Haydn, Rolla, Pleyel etc., as well as overtures by Guglielmi (Debora e Sisara), Portogallo (I due gobbi) and others are listed (Dubrovnik, Samostan Male braće, Glazbena zbirka; reproduced with kind permission). 
who was from the same generation, although actually his second uncle. According to the preserved musical material, Paolo Baldasare played the violin ${ }^{10}$ and possibly also the flute. His parents and close relatives were highly educated: his mother was a poetess, and his famous uncle Tommaso (Tomo Bassegli, 1756-1806), educated in Switzerland, played the flute and the harp. It is possible that Tommaso bequeathed the flute music to his nephew Paolo. When Paolo inherited his mother's property, he added her maiden name - therefore, some of his music features the signature Bassegli-Gozze.

The Elenco della musica vocale e istrumentale attinente al Sig. Paolo Gozze (List of the vocal and instrumental music belonging to Sig. Paolo Gozze) is a booklet of nineteen pages laid out according to musical genre: sestetti e quintetti, quartetti, trij, duetti (chamber music); concerti (for flute and for violin) and pieces for the solo violin; these are followed by vocal music consisting of arias and duets from operas and songs with often unspecified instrumental accompaniment. The section "Sinfonie" can induce some confusion since both operatic overtures and free-standing instrumental symphonies are included without any precise differentiation between them (see Figs. 1a and 1b). The lack of more complete information, probably occasioned by haste in the compilation of the list, is obvious in all its sections. It is therefore not possible to make a full reconstruction of the contents of Gozze's musical library from this list alone: in addition to the absence of important details in the description of the material (manuscript or print; score or parts), a complete title or opus number is often lacking. This additional information has to be sought among the preserved items of sheet music.

Table 1 List of composers (with at least 4 works) in the catalogue

\begin{tabular}{|l|r|}
\hline Composer & No. of Items \\
\hline Pleyel, I. & 27 \\
\hline Haydn, J. & 20 \\
\hline Pichl, W. & 9 \\
\hline Farinelli, G. & 7 \\
\hline Paisiello, G. & 7 \\
\hline Mozart, W. A. & 7 \\
\hline Baldan, P. & 5 \\
\hline Cimarosa, D. & 5 \\
\hline Vranitzky, P. & 5 \\
\hline Beethoven, L. van & 4 \\
\hline Hoffmeister, F. A. & 4 \\
\hline
\end{tabular}

The majority of the compositions listed are instrumental. In all, there are 233 entries representing ninety-one composers. For three authors, only the initials are given, and three items are anonymous. Some titles are listed in more than one section, so the true number

letters, for which reason this form appears very often in modern literature.

${ }^{10}$ E.g., Momolo [Girolamo] Ricci: Posizioni p. Violino (Dubrovnik, Franjevački samostan Male braće, knjižnica (HR-Dsmb), 75/1966) and Arpeggi per Violino (HR-Dsmb, 75/1965), written for Paolo Gozze. 
of works comes down to some 220 titles. The composers with the most compositions are Ignaz Pleyel (with twenty-seven titles), Joseph Haydn (twenty), Wenzel Pichl (nine), W. A. Mozart, Giovanni Paisiello and Giuseppe Farinelli (seven each) - see Table 1.

The predominance of Central European - indeed, Austrian - composers in Mediterranean Dubrovnik provides evidence of the new political directions being taken already at the end of the eighteenth century, leading towards the new political map drawn in 1815, when Dubrovnik became part of the Habsburg Empire. Certainly, both Pleyel and Haydn were already recognized during their lifetimes as the most popular composers in lands lying outside their cultural milieu. Their compositions were therefore performed also in the Italian states, and from Italy travelled to collections in Dalmatia.

\section{The Owners of Musical Material from the Gozze Family Preserved in the Music Collection of the Friars Minor}

The individual ownership of the musical material belonging to members of the Gozze family is somewhat clarified by the preserved copies in the monastery of the Friars Minor in Dubrovnik, where some two hundred items (individual compositions as well as collections) bearing the Gozze signature are kept: there we encounter the names of Paolo, Giacomo, Melchiore and Vladislas Paul, as well as the less precise appellations Gozze, Casa Gozze, Comte du Gozze and Bassegli-Gozze.

Melchiore di Gozze (Melko Baldov Gozze, 1787-1853), whose signature is found on nine pieces of music, was Paolo's brother. Judging from his musical possessions, he probably played the piano, but he also liked operatic arias by Paisiello, Boriani and Portogallo. It is also possible that he himself used to sing, as we may infer from the dedication of one aria ("Per uso del Nobil Fanciullo il Sig. Melchiorre di Gozze," HR-Dsmb, 9/225), "Se di tacer v'impongo" by Tommaso Resti, who may have been his teacher. On two music prints we encounter the signature of Giacomo Gozze, probably Paolo's and Melchiore's father with the full name of Baldassare-Giacomo (di Paolo) Gozze (Jakopica Gozze, 1745-1817), ${ }^{11}$ whose musical education is still unknown.

Finally, Vladislas Paul de Gozze (Vladislav Pavov Gozze, 1788-1859), a member of a different Gozze clan but Paolo's and Melchiore's contemporary, obviously learned the piano, since pieces for that instrument by Steibelt and Clementi carry his signature. ${ }^{12}$ In 1822, Vladislas Paul founded the new Dubrovnik theatre. His interest in stage and recreational music is also evident from the Franciscan collection, although the Elenco probably does not list any of his musical material.

Only about sixty items in the Franciscan collection cannot be matched to any entry in the catalogue, whereas almost 130 entries in the catalogue have their original material

${ }^{11}$ Vekarić, Vlastela, 4:83.

${ }^{12}$ For example, a manuscript volume entitled Regole musicali per principianti di cembalo once owned by Vladislav Pavlov Gozze (Vladislas Paul de Gozze) in HR-Dsmb, 206/5384, as well as an Etude pour le Piano-Forte by Daniel Gottlieb Steibelt and sonatas by Clementi in HR-Dsmb, 27/857, 58/1620-21. 
still preserved (amounting to more than half the listed items). Next to many titles in the catalogue, numbers have been added, and many of these match numbers present on the items of sheet music (but the numbering system is neither clear nor precise).$^{13}$

The taste and the artistic level of some of the owners can be assessed from their choice of works to collect: there are primers for music theory and violin playing (for Paolo Gozze), ${ }^{14}$ and also for the piano (for Vladislas Paul). ${ }^{15}$ Further, there are chamber works, probably used for domestic music-making, ${ }^{16}$ and even some quite demanding concertante and symphonic works, which could have been played with assistance from members of the Rector's orchestra or other professionals. The noble musicians naturally participated in such performances only at domestic "academies" in a private setting.

The Gozze musicians acquired mostly more or less recent musical repertoire, running from the mid-eighteenth century (represented by sonatas of Giuseppe Tartini), to arrangements of arias from the contemporary music stage. This material reached Dubrovnik mostly from neighbouring countries, predominantly Italy. Only a small number of exceptions originated from the city itself: these were two symphonies composed by Antun Sorgo (1775-1841), which were dedicated to his friends (among them was Paolo Gozze), and two arias composed by Tommaso Resti, one of the most important composers in Dubrovnik, who came from Lecce in Apulia. Both of the latter bear the signature of Melchiore Gozze, who may even have been a pupil of Resti. ${ }^{17}$ Vladislas Paul collected dance melodies in two volumes: Monferine suonate da Ragusa (HR-Dsmb, 52/1474) and Eccossais joués à Raguse (HR-Dsmb, 52/1473).

Some manuscripts acquired in Italy testify to operatic production in well-known theatres. It is possible that members of the Gozze family bought them at the point of their initial sale. For example, Paolo Gozze's score of the "Rondò" aria for soprano and orchestra "Se ti lascio o mio tesoro" by Gaetano Andreozzi notes its performance at the Venetian theatre of San Benedetto in the Ascension season of 1788 (HR-Dsmb, 1/16); similarly, the cavatina "Benedetta di Campagna" by Francesco Orgitano, performed at the Teatro San Moisè in 1801 (HR-Dsmb, 24/744), and the aria "A che giova esser gelosi" by Giuseppe Mosca, performed at the same theatre in spring 1809 (HR-Dsmb, 41/1180).

There are also various inscriptions referring to the copyists of the material, and

${ }^{13}$ In the catalogue, numbers up to 1200 can be found, but with many gaps in between. Moreover, it is not possible to link numbers to specific musical genres. For example, some symphonies are numbered fifty-six, while others bear the numbers four or three hundred. Some numbers occur repeatedly on diverse items, albeit only sporadically. When the original musical material was inspected, its numbers corresponded to those of the matching entry in the catalogue. It is therefore possible that these numbers denote a sequence of acquisition by the family library, musical and non-musical items perhaps forming a single series.

${ }^{14}$ See earlier, n. 8.

${ }^{15}$ See earlier, n. 10.

${ }^{16}$ An example of an original piece is Haydn's Eco per quattro violini, e due violoncelli da eseguirsi in due camere, Naples: Marescalchi, n.d. [1793?] (HR-Dsmb, 166/4620; see Fig. 2). There is also a series of trios, quartets, quintets and sextets.

${ }^{17}$ These are the cavatinas "Non voglio più darmi" and "Se di tacer v'impongo" for soprano and strings (HR-Dsmb, 9/224 and 225), the second of which bears the inscription "Per uso del Nobil Fanciullo il Sig. Melchiore di Gozze." 


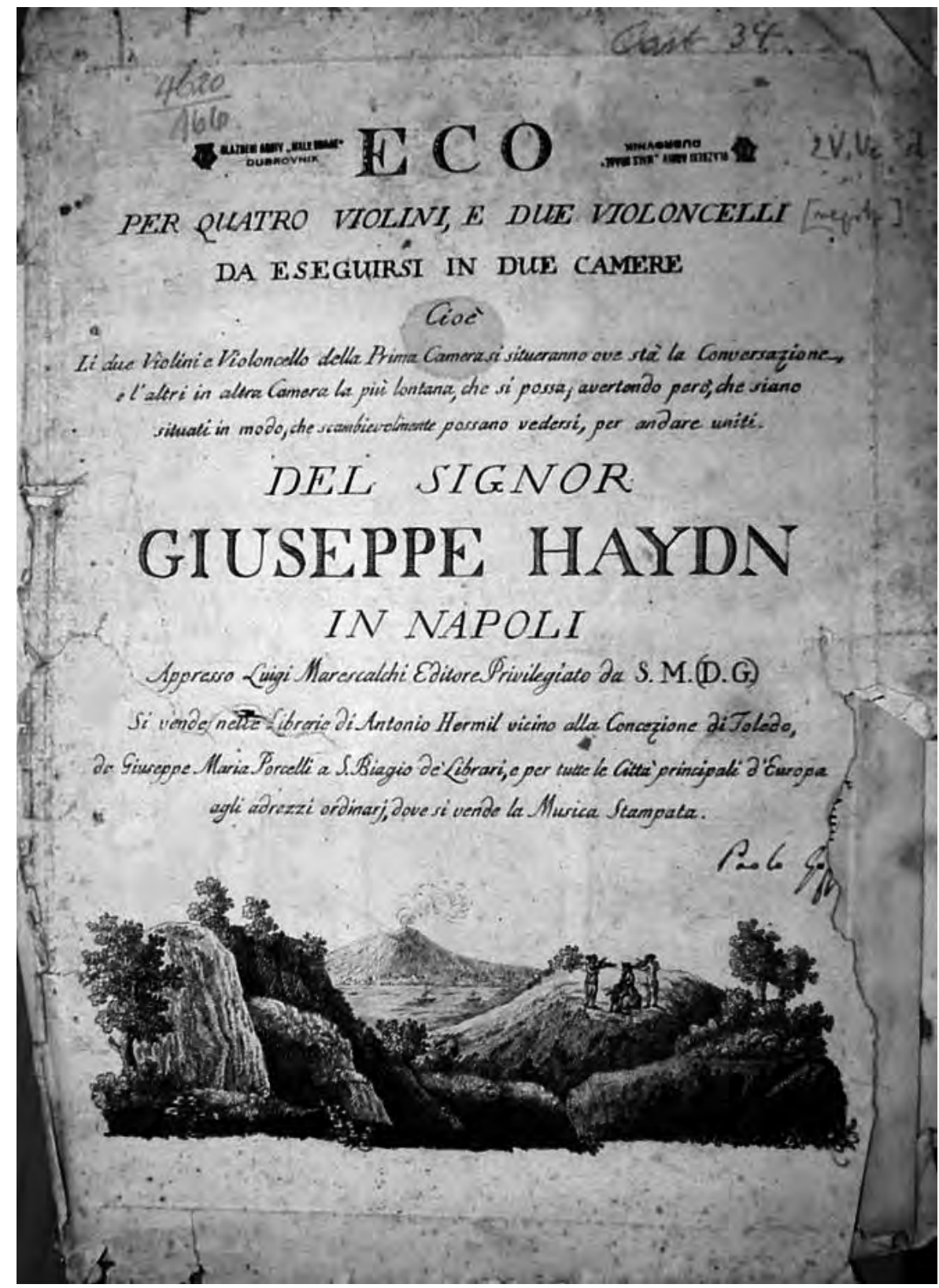

Figure 2 Title page of Haydn's Eco for the string ensemble, which should be performed in two rooms in order to produce the echo effect. A signature by Paolo Gozze was partly torn; the shelf no. 166/4620 and "Cart.[ellone] 34" were written by Ivan Evanđelist Kuzmić, the friar who brought the material to the monastery in the mid-nineteenth century, and other remarks on the preserved parts was written by Albe Vidaković, who was the first to make the new catalogue of the Franciscan collection during the 1950s (Dubrovnik, Samostan Male braće, Glazbena zbirka, 166/4620; reproduced with kind permission). 
some of these identify the copisteria, its location and the names of copyists. For example, a concerto for violin and orchestra by Dittersdorf (in B) was copied by "Don Giuseppe Baldan Coppista di Musica a S. Giov: Grisostomo. Venezia" (HR-Dsmb, 3/62). ${ }^{18}$ It is possible that this man was related to the Venetian composer Angelo Baldan, ${ }^{19}$ whose two symphonies are also preserved in Paolo Gozze's collection at the monastery (HR-Dsmb, 37/1044 and 1045).

Table 2 Publishers represented in the preserved music publications owned by the Gozze family

\begin{tabular}{|l|c|c|c|}
\hline Publishers & In the Catalogue & Not in the Catalogue & Total \\
\hline Berlin and Amsterdam: Hummel & 1 & 1 & 2 \\
\hline Florence: Pagni e Bardi & 1 & 2 & 3 \\
\hline Florence: Ranieri del Vivo & 1 & 1 & 1 \\
\hline Leipzig: Breitkopf \& Härtel & 0 & 1 & 1 \\
\hline London: J. Bland & 1 & 1 & 2 \\
\hline London: Longman \& Broderip & 0 & 0 & 1 \\
\hline Mainz: Schott & 1 & 1 & 1 \\
\hline Naples: Marescalchi & 4 & 1 & 5 \\
\hline Offenbach: André & 2 & 0 & 3 \\
\hline Paris: Pleyel & 1 & 0 & 1 \\
\hline Paris: Érard & 3 & 1 & 3 \\
\hline Paris: Mad. Duhan \& Co. & 0 & 3 & 1 \\
\hline Venice: Zatta & 12 & 10 & 15 \\
\hline Vienna: Artaria & 10 & 3 & 20 \\
\hline Vienna: Hoffmeister & 2 & 2 & 4 \\
\hline Vienna: T. Mollo & 0 & 1 & 1 \\
\hline Vienna: T. Weigl & 0 & 1 & 1 \\
\hline Vienna: L. Maisch & 0 & 3 & 3 \\
\hline Vienna: Magazin de musique & 3 & 0 & 77 \\
\hline No mention of the publisher & 45 & 32 & \\
\hline TOTAL: 19 PUBLISHERS & & & 3 \\
\hline
\end{tabular}

The copyists evidently had fixed tariffs, as in the case of Lodovico Massaglia, who charged half a piastre per foglio (i.e. for four leaves) ${ }^{20}$ His name occurs on quite a number of Dubrovnik manuscripts, and also on ones found in very distant locations - his copy of

${ }^{18}$ Giuseppe Baldan was a very active copyist in Venice, especially of the oeuvre of Baldassarre Galuppi (Buranello; RISM lists fifty-four items by him copied by Baldan) and some other contemporaries. On the other hand, this manuscript of the Dittersdorf concerto is also identified as a piece "Per uso della Sig.r ${ }^{\text {ra }}$ Baronesa Stigliani," so it probably did not come to Dubrovnik directly from Baldan's establishment.

${ }^{19}$ Hansell, "Angelo Baldan," 529.

${ }^{20}$ For a copy of an arrangement for string quartet comprising ten numbers from Cimarosa's Gli Orazi ed $i$ Curiazi (premiered at the Neapolitan theatre of San Carlo in 1795) he charged six piastres for twelve fogli, and two piastres for the four fogli of a single aria by Gardi (HR-Dsmb, 19/649). 
some fragments from Generali's opera Pamela nubile even found its way to the collection of Mikhail Sergeyevich Vorontsov in Moscow. ${ }^{21}$

The shift of interest towards France and French culture already evident at the turn of the eighteenth and nineteenth centuries, the abolition of the Republic of Dubrovnik in 1808, the Napoleonic government and the gradual change in social relations also left their traces on the Gozze material. Besides the titles in French (adopted also by Viennese publishers), there are occasional revelatory remarks on the provenance of manuscripts: for example, a collection of French romances for voice with simple instrumental accompaniment is labelled "Paris 1810." In the collection are also two pieces by Antun Sorgo, and the author of one of the texts was Paolo Gozze. Moreover, some seventy prints (both in the catalogue and in the music collection) date from that same period, having been purchased by members of the Gozze family from various European publishers. Pride of place is taken by Viennese publications, with thirty-five examples by Artaria (twenty), Hoffmeister, T. Mollo, L. Maisch, T. Weigl and Magasin de musique. These were owned mostly by Vladislas Paul. They are followed by twenty-three Italian ones from Venice, Florence and Naples, mostly published by Zatta e Figli (Venice), which were almost entirely owned by Paolo Gozze. There are also some French, German and even British publications (see Table 2).

\section{Conclusion}

The information provided on the discussed sheet music, as well as the material owned by other Dubrovnik families, testifies to its provenance, proving that the local nobility had a wide ambit of education and interests, not only in literature and philosophy (as proven by their libraries), but also in music. Unlike artists in Dalmatia, who were oriented mostly towards the Venetian Republic (Venice, Padua, Bologna etc.), the nobility of Dubrovnik had the opportunity to enjoy direct contact with many European cities on account of their extensive maritime trade and diplomatic relations. When travelling abroad, they took the opportunity to acquire various objets d'art as well as musical material, books etc. Musical education formed part of their intellectual development, and its results were intended to be displayed exclusively in private surroundings. Their teachers were either local musicians or ones from outside Dubrovnik (for example, Paolo Gozze's Venetian violin teacher Momolo Ricci), but they never made an effort - or did not possess the skills - to be creative in music and compose in the manner of their noble contemporaries from the Sorgo family.

They reoriented the direction of their musical (and general) interests in line with the

${ }^{21}$ See Moscow, Naučnaja muzykal'naja biblioteka im. S. I. Taneeva Moskovskoj gosudarstvennoj konservatorii im. P. I. Čajkovskogo, XYП I-II66. It is possible that this person is actually Mikhail Semyonovich Vorontsov (1782-1856), the son of Semyon Romanovich Vorontsov (1744-1832), an outstanding diplomat serving the Russian empress in London (1784-1806), who received an exquisite education in London and was later created a field-marshal. 
developing political, social and cultural situation: from neighbouring Italy towards the enlightened Austria (of Joseph II), and later on towards France.

Finally, the lack of detailed general information on the life and work of four Gozze family members has prompted a musicologist to investigate the musical aspect of their activity, thereby contributing to a deeper insight into their lives and leisure-time as well as into the broader picture of Dubrovnik's intellectual everyday life.

\section{Bibliography}

Beritić, Nada. “Iz povijesti kazališne i glazbene umjetnosti u Dubrovniku.” In Otkrića iz arhiva. Split: Književni krug, 2000.

Ćosić, Stjepan, and Nenad Vekarić. Dubrovačka vlastela između roda i države. Zagreb: HAZU, Zavod za povijesne znanosti u Dubrovniku, 2005.

Demović, Miho. Glazba i glazbenici u Dubrovačkoj Republici od sredine XVII. do prvog desetljeća XIX. stoljeća. Zagreb: JAZU, 1989.

Hansell, Sven. "Baldan, Angelo.” In The New Grove Dictionary of Music and Musicians, 2nd ed., edited by Stanley Sadie, 2:529. London: Macmillan, 2001.

Katalinić, Vjera. "Glazbeni arhiv samostana Male braće u Dubrovniku: rani rukopisi od početka 18. st. do oko 1820.” In Samostan Male braće u Dubrovniku, edited by Justin Velnić, 623-664. Zagreb: Kršćanska sadašnjost, Samostan Male braće, 1985.

Krivošić, Stjepan. Stanovništvo Dubrovnika i demografske promjene u prošlosti. Dubrovnik: Zavod za povijesne znanosti JAZU u Dubrovniku, 1990.

Tuksar, Stanislav. "Glazbeni arhiv Samostana Male braće u Dubrovniku: opći pregled fonda i popis ranih tiskovina." In Samostan Male braće u Dubrovniku, edited by Justin Velnić, 665-773. Zagreb: Kršćanska sadašnjost, Samostan Male braće, 1985.

Vekarić, Nenad. Vlastela grada Dubrovnika. Vols. 3 and 4. Zagreb: HAZU, Zavod za povijesne znanosti u Dubrovniku, 2012-2013. 


\section{TUJE MUZIKALIJE DUBROVNIŠKE DRUŽINE GOZZE}

\section{Povzetek}

Dubrovniška družina Gozze, ena od najstarejših plemiških družin Dubrovniške republike, se je ponašala s člani, ki so bili odlično izobraženi v literaturi in filozofiji, in so ob članih družine Sorkočević (Sorgo) zasedali najvišje državne upravne položaje. Dokazi in neposredni viri so se ohranili v dubrovniškem frančiškanskem samostanu, kjer hranijo tudi enega najobsežnejših in najpomembnejših glasbenih fondov na Hrvaškem. Od sredine 19. stoletja so v zbirko vključene muzikalije dubrovniških patricijev in med njimi tudi katalog muzikalij Paola (Pavao) Gozze. Poleg tega lahko zahvaljujoč se podatkom o muzikalijah te zbirke in njihovi celoviti računalniški obdelavi ugotovimo, da se je v zbirki ohranil tudi del notnega gradiva tega plemiča, in sicer v obliki številnih rokopisov in glasbenih tiskov skladb iz 18. in začetka 19. stoletja.

Članek prinaša pregled teh muzikalij, skladateljev, ki so v njih zastopani, založnikov, pa tudi rokopisnih beležk in njihovih izvorih, o lastnikih obravnavanih muzikalij iz širše družine Gozze (poleg Paola so bili lastniki glasbe tudi njegov brat Melchiore ali Melko, oče Giacomo, tudi Jakopica, ter sorodnik Vladislav Pavlov).

Glasbeni tiski so bili nabavljeni povečini v tujini - v Italiji, v Avstriji, v Franciji in celo v Angliji. Rokopisna glasba pa je prihajala predvsem iz italijanskih mest, o čemer govorijo razne beležke o prepisovalcih, krajih in datumih izvedb, o izvajalcih ipd.

Na podlagi teh podatkov lahko sklepamo o načinih pridobivanja teh not, za koga so bile nabavljene in celo o glasbeni izobrazbi njihovih lastnikov. Precej lahko razberemo o glasbeni izobrazbi članov družine Gozze (ta je kot primer obravnavana v pričujoči razpravi), pa tudi po analogiji o večjem delu dubrovniškega plemstva na koncu 18. in v začetku 19. stoletja. 